\title{
Use of Markov chains for modeling processes of strategic planning of innovative activity of the enterprise
}

\author{
K. DOROSHKEVYCH ${ }^{1}$, O. MASLAK ${ }^{1}$, V. VORONOVSKA ${ }^{1}$, I. SALATA ${ }^{2}$ \\ ${ }^{1}$ Institute of Economics and Management \\ Lviv Polytechnic National University \\ 79013 Lviv, 12 Bandera str. \\ ${ }^{2}$ Hetman Petro Sahaidachnyi National Army Academy \\ 79026 Lviv, 32 Heroes of Maidan street. \\ UKRAINE \\ kateryna.o.doroshkevych@lpnu.ua
}

\begin{abstract}
The article investigates the processes of strategic planning of innovative activity of the enterprise as an activity to determine the directions of enterprise innovative activity (strategy), which would be consistent with the available resource provision, innovative potential of the enterprise and meet the needs of the market and have a reasonable use of the mathematical apparatus of Markov chains for its modeling. The article gives examples of practical use of Markov chains in the management of innovative projects, forecasting the structure of the existing land fund of Ukraine, in the tasks of buying and selling shares, allocation of financial resources between executors of investment projects in a closed system, etc. Markov chain is used to model strategic planning of innovative activity of the enterprise.
\end{abstract}

Key-Words: strategy, innovative activity, planning, enterprise, Markov chain, forecasting.

Received: January 6, 2020. Revised: May 24, 2020. Accepted: May 30, 2020. Published: June 7, 2020

\section{Introduction}

As you know, business entities are open systems that interact with the environment, consuming resources and creating products, services and other results of their activities. Enterprises operate under conditions of competitive environment and dynamic change of external environment of activity. These circumstances, among other things, require careful attention to the issues of planning the activity of the enterprise, which create the conditions of certainty of its functioning and risk reduction.

In terms of innovative development, planning involves a set of measures for the development of planned tasks in the innovative process and their implementation in the practice of enterprises [1]. These tasks are related to the definition of goals and the formation of plans of innovative activities, which would be consistent with the available resources, innovative potential of the enterprise and meet the needs of the market. The efficiency and utilization of the existing innovative potential of the enterprise, the effectiveness of its innovative projects, etc., depend on the level and provision of planning processes.

Strategic and operational planning is implemented in the practice of enterprise innovative management. Strategic planning involves determining the direction of innovative activity of an enterprise (strategy), and operational planning is its logical continuation and a way to implement the strategy of innovative activity [2]. Strategic planning is implemented in order to provide the market with the needs of the course of development of innovative activity of the organization, to enhance its ability to anticipate changes in the external environment and to respond to them. Therefore, we propose to focus more on strategic innovative planning in further research.

At the same time, the complexity of production and economic activity of enterprises and the need for future orientation require modeling of phenomena and processes that accompany their functioning and prediction of future states. For strategic direction, models should be used in the enterprise management process that simplify the management situation and allow it to be observed. Various models (physical, analog, mathematical) are used in enterprise's management practice. Those methods of constructing include various mathematical tools, to which the Markov chain belongs. It can be considered as an approach to solving the problem of planning from the standpoint of process modeling [3]. 


\section{Problem Formulation}

A Markov chain is a set of elements that are identified as its states. The set can move from one state to another at specific times (steps). That is, at time $t$, the set (process, system) may be in a certain state and go with a certain probability to another state over a period of time $t+1$. The Markov chain is based on the assumption that the state of a system in the time period $t+1$ depends on its previous state (in period $t$ ) and does not depend on its pre-previous states (in period $t-1, t-2$ ). In addition, changes in system states occur under the influence of random factors. The total number of system states is counted and finite [4]. Markov chains acquire different traits (homogeneous, simple, discrete, etc.) depending on the level of spatial states and the nature of the observed processes $[5,6]$.

Thus, in order to improve the effectiveness of strategic planning of innovative activity of the enterprise, its modeling should be provided. To realize these goals, let us explore the possibility of using a Markov chain.

\section{Problem Solution}

The use of the Markov chains in the process of enterprise management has been implemented in the works of such scientists as Skitsko V. I., Koshkina K. V.., Ikhsanov Sh. M., Lopushanska V. V., Prystavka P. O., Tyvodar O. V., Olekh T. M., Lapshyn V. I., Kuznichenko V. M., Aliiev F. M., Babenko V. O. etc. [2-3, 7-15].

Skitsko V.I. substantiated the use of Markov chains to make estimates of the main indicators of the credit policy of the company: the volume of sales of products and the average amount of overdue receivables without taking into account the period of its repayment [7]. On the basis of using the developed model, enterprises can justify management decisions regarding cooperation with potential contractors, evaluate alternative cooperation options under different conditions. As a result, the effectiveness of the credit policy of the company increases.

Kolesnikova K. V. used Markov chains to build a unified model of project management and to substantiate Koshkina's K. V. law on the variability of design processes that affect the quality of the project and the expected results of its implementation. The unified Markov model of projects recommended by Kolesnikova K.V. provides modeling of parameters of a course of realization of projects, changes of probability of its states. This allows to build a trajectory of project implementation, identify the number of steps required to achieve the goal of projects [8]. Recommendations on the use of the Markov chains in project management were also provided by Olekh T. M., who investigated the multidimensional evaluation process in project management [9].

Ikhsanov Sh. M., Lopushanska V. V. have used Markov chains for forecasting the structure of the existing land fund of Ukraine. At the same time, the authors investigated the probability of the system transition from one state to another and the reliability of the forecasts obtained regarding the structure of the land fund of Ukraine [10].

A model based on Markov chains was developed by Prystavka P. O. and Tyvodar O. V. The model should be used in the decision making of buying and selling stocks. The authors have formed a graph of the state of the stock price behavior system and the differential equation system that describe it. Afterwards, the system of equations was simplified by taking into account the asymmetry coefficient, which proved the leftasymmetry of the interval distributions of the system's residence time in the states. The simplified equation system is decoupled and obtained graphical visualization of the results. The researchers evaluated the probabilities of states that determine the strategy of further actions of stock market participants, based on the developed model [3].

Lapshyn V. I., Kuznichenko V. M. considered a probabilistic approach to a scarce model of allocation of financial resources between contractors of investment projects in a closed system based on the use of Markov chains and the z-transform method [11]. By using the z-transform method and the defined analytical form, the enterprise's management apparatus can obtain the necessary information regarding the distribution of the company's budget, as well as sales and purchases budgets between partners at each step of the Markov chain, etc.

It is also possible to control the flow of material flows, which indicates the versatility and efficiency of this method, which is proved by the example of agro-industrial enterprises, using the Markov chain [12].

The Markov chain and the Monte Carlo method have been widely used in economic research. Ruslan Salakhutdinov and Andriy Mnih 
recommend using Markov chain Monte Carlo methods to train Bayesian PMF models, which is applied to the Netflix dataset [16]. This method is mostly called Markov chain Monte Carlo (MCMC) and is used for approximate inference in Factorbased models, proposed by Peskun P. H. [21].

Going beyond the economics, Markov chains have found their application in predicting protein subcellular locations, in computational Statistics for the sampling from the posterior distribution of a Dirichlet process mixture model. The Markov chains model was used to develop the bridge performance prediction model (as a part of comprehensive bridge management system for the Indiana Department of Highways (IDOH)), for understanding (investigating) memory and structure of human navigation on the Web etc. [18-25].
Based on the analysis of recent research and publications on the problem, we would note the widespread using of Markov chains in modeling socio-economic phenomena and processes. This gives grounds for its application in the study of strategic planning of innovative activity of the enterprise.

As you know, strategy is a comprehensive plan for the future development of an organization, which is determined in strategic planning process. Its detailing is ensured by defining planned parameters on the basis of which strategic and current plans of activity of the enterprise are formed [2].

The states of processes of strategic planning of innovative activity of the enterprise can be described in fig. 1.

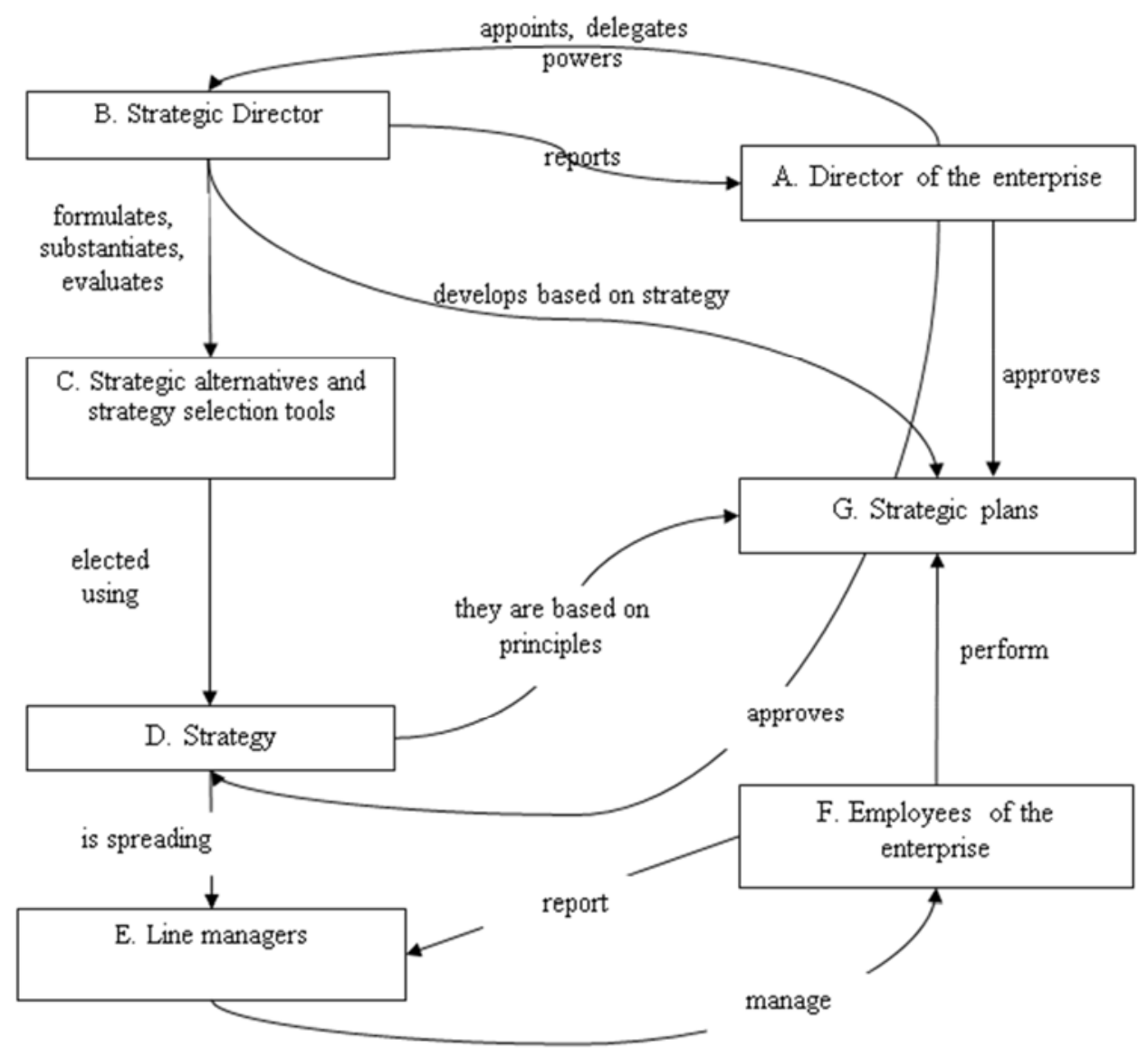

Fig. 1. The states of strategic planning processes of enterprise innovation activity

As a rule, strategic planning at the enterprise is carried out by the strategic director (strategy director, chief of strategic development department, etc.), who is appointed by the director of the enterprise, which delegates the relevant powers to him. They consist in the implementation of strategic planning stages, in the process of which strategic alternatives are identified, the tools for strategy selection are determined and so on. By their use at the enterprise the strategy of its activity is selected and approved by the (director), on the basis of which strategic plans are formed. Those strategic plans are developed by the strategic director, who controls their implementation and are approved by the director of the enterprise. Strategy and strategic plans are distributed among the 
company's employees through the line managers. They manage employees to execute strategic plans that they are report on.

In the above order of processes (Fig. 1), the identifiers of the states of the strategic planning process of innovative activity of the enterprise are the blocks marked through A, B, C, D, E, F, G. enterprises.

We transform the order of strategic planning of innovative activity of the enterprise into Markov chain (Fig. 2), using state identifiers of strategic management of enterprise innovative activity (Fig. 1). At the same time, we assume the states of the process of strategic planning of innovative activity of the enterprise (A, B, C, D, E, F, G) for a finite set of integers $\mathrm{Si}\{1,2,3, \ldots, 7\}$, whose elements are identified by the identifiers states of strategic planning of innovative activity of the enterprise: $S_{1}$ $=\mathrm{A}, \mathrm{S}_{2}=\mathrm{B}, \mathrm{S}_{3}=\mathrm{C}, \mathrm{S}_{4}=\mathrm{D}, \mathrm{S}_{5}=\mathrm{E}, \mathrm{S}_{6}=\mathrm{F}, \mathrm{S}_{7}=\mathrm{G}$.

In the Markov chain of strategic planning for enterprise innovation, we will show the connections between the elements of the set $\mathrm{Si}$ $\{1,2,3, \ldots, 7\}$, which will be indicated by arrows, providing a guiding influence that leads to a system update without any external influence. The Markov chain graph of strategic planning of innovative activity of the enterprise (Fig. 2) indicates the transition probabilities of states of strategic planning of innovative activity of the enterprise $(\pi \mathrm{i}$, j) according to the described in Fig. 1 connections between elements of the set $\mathrm{Si}\{1,2,3, \ldots, 7\}$.

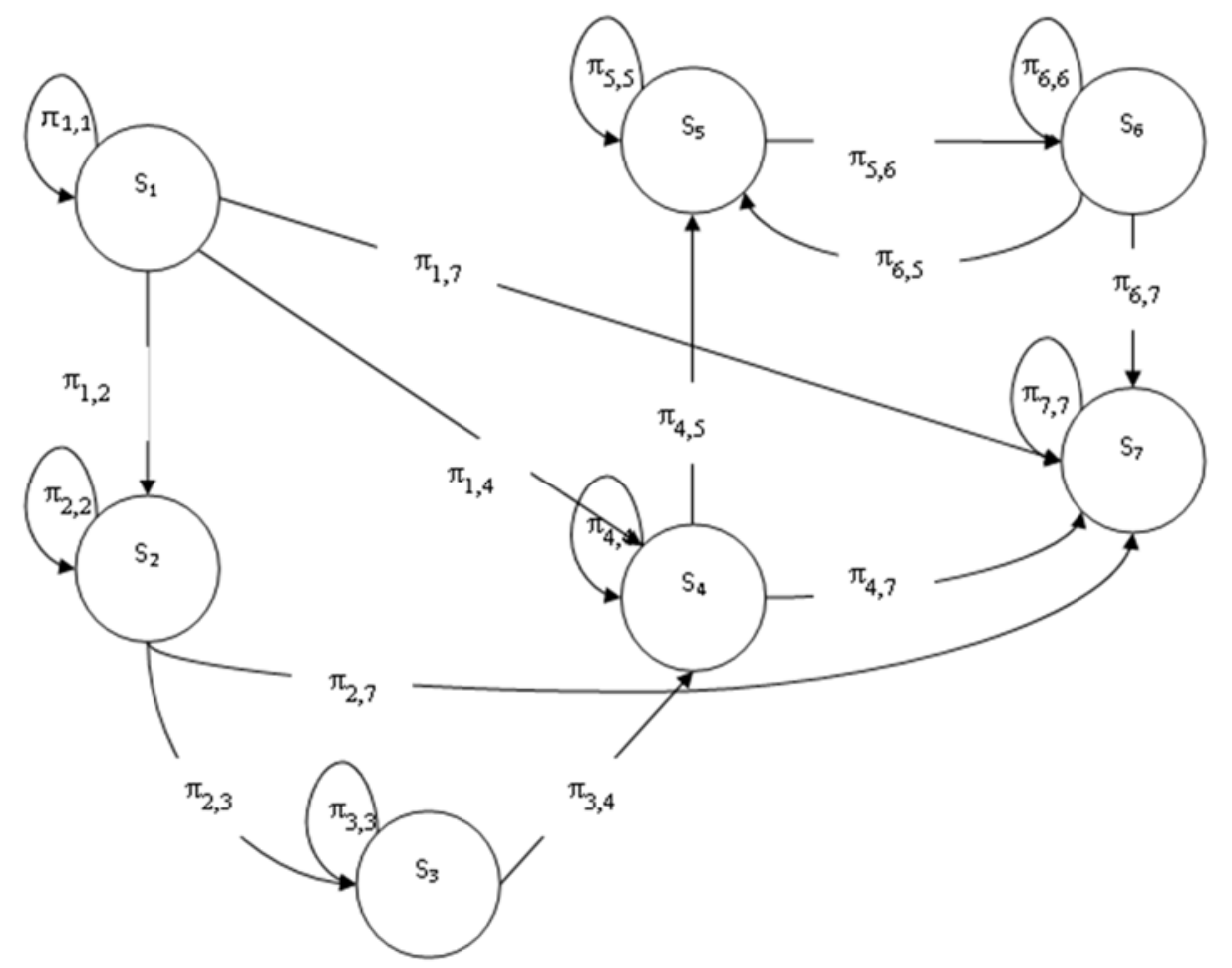

Fig. 2. Markov chain graph of strategic planning of innovative activity of the enterprise

Note: $\pi_{1,1}$ - the probability of $S_{1}$ transitioning to a new state; $\pi_{1,2}$ - the probability of transition $S_{1}$ to $S_{2} ; \pi_{1,4}-$ the probability of transition $S_{1}$ to $S_{4} ; \pi_{1,7}$ - the probability of transition $S_{1}$ to $S_{7} ; \pi_{2,2}$ - the probability of $S_{2}$ transitioning to a new state; $\pi_{2,7}$ - the probability of transition $S_{2}$ to $S_{3} ; \pi_{2,7}$ - probability of transition $S_{2}$ to $S_{7}$; $\pi_{3,3}$ - the probability of $S_{3}$ transitioning to a new state; $\pi_{3,4}$ - probability of transition $S_{3}$ to $S_{4} ; \pi_{4,4}$ - the probability of $S_{4}$ transitioning to a new state; $\pi_{4,5}$ - probability of transition $S_{4}$ to $S_{5} ; \pi_{4,7}$ - probability of transition $S_{4}$ to $S_{7} ; \pi_{5,5}$ - the probability of $S_{5}$ transitioning to a new state; $\pi_{5,6}$ - probability of transition $S_{5}$ to $S_{6}$; $\pi_{6,6}$ - the probability of $S_{6}$ transitioning to a new state; $\pi_{6,5}$ - probability of transition $S_{6}$ to $S_{5} ; \pi_{6,7}$ - probability of transition $\mathrm{S}_{6}$ to $\mathrm{S}_{7} ; \pi_{7,7}-$ the probability of $\mathrm{S}_{7}$ transitioning to a new state.

It is known that the Markov chain reflects the process of changing the states of the set $\mathrm{Si}$ $\{1,2,3, \ldots ., 7\} \mathrm{k}$ over a period of time $(\mathrm{k})[8]$. In this case, the probability of states can be denoted as pi $(\mathrm{k})$. Then, the sum of the probabilities of the states of pi in each of the time periods $(\mathrm{k})$ is equal to one [8]:

$$
\sum_{j=1}^{m} p_{i}(k)=1 .
$$

The properties of the Markov chain and equation (1) and the probability over a period of time $(\mathrm{k}+1)$ can be determined as follows:

$$
p_{i}(k+1)=p_{i}(k) * \pi_{\mathrm{i}, \mathrm{j}} .
$$


$\sum_{\mathrm{i}=1}^{n} p_{i}(k+1)=\sum_{j=1}^{m} p_{i}(k) * \pi_{\mathrm{i}, \mathrm{j}}$

where $\mathrm{i}=1,2, \ldots 7$ are the rows of the probability matrix of the states of strategic planning of innovative activity of the enterprise in the corresponding period of time and the transition probability matrix;

$j=1,2, \ldots 7$ - these are the columns of the probability matrix of the states of strategic planning of innovative activity of the enterprise in the corresponding period of time and the matrix of transitional probability.

To use the described equations (1-3), according to the formed Markov chain (Fig. 2), we generate a matrix of probabilities of transition between the states of the strategic planning processes of innovative activity of the enterprise $(\pi \mathrm{i}, \mathrm{j})$, the number of rows and columns of which is equal to 7 $\{i=1, \ldots, 7 ; j=1, \ldots, 7\}$ :

$$
\left\|\pi_{i, j}\right\|=\left\|\begin{array}{ccccccc}
\pi_{1,1} & \pi_{1,2} & 0 & \pi_{1,4} & 0 & 0 & \pi_{1,7} \\
0 & \pi_{2,2} & \pi_{2,3} & 0 & 0 & 0 & \pi_{2,7} \\
0 & 0 & \pi_{3,3} \pi_{3,4} & 0 & 0 & 0 \\
0 & 0 & 0 & \pi_{4,4} & \pi_{4,5} & 0 & \pi_{4,7} \\
0 & 0 & 0 & 0 & \pi_{5,5} & \pi_{5,6} & 0 \\
0 & 0 & 0 & 0 & \pi_{6,5} & \pi_{6,6} & \pi_{6,7} \\
0 & 0 & 0 & 0 & 0 & 0 & \pi_{7,7}
\end{array}\right\| .
$$

The Markov chain transition probability matrix, characterizing the strategic planning of innovative activity of the enterprise (4) is used to determine the transition probabilities between the states of strategic planning of innovative activity of the enterprise processes (Fig. 1) in the long run. To achieve these goals, it is necessary to evaluate the elements of the matrix of transient probabilities of states (4), for which it is recommended to use the method of expert estimation and equality:

$$
\sum_{j=1}^{m} \pi_{i, j}=1, i=\{1,2, \ldots, \mathrm{m}\} .
$$

Equality (5) indicates that the state of probabilities of transition states at each step of strategic planning of innovative activity of the enterprise is equal to 1 [8].

Let us carry out modeling of strategic planning of innovative activity of Ltd. TMC «Lvivholod», for which we will use the recommended Markov Chain Graph (Fig. 2). Using expert judgment methods, we will form a matrix of transitional probabilities of Markov chain of Ltd. TMC «Lvivholod», between the states of strategic planning processes of innovative activity of the enterprise. For this purpose, we have used the expert group of employees of Ltd. TMC «Lvivholod», specialists of the National University «Lviv Polytechnic» and Center for Strategic Research and Analysis (www.csda.in.ua). The total number of experts was 12 , what is sufficient for forming a matrix and researching. Experts evaluated the transient probabilities between states during the questionnaire survey, moreover, the generalized estimation of the transient probabilities was calculated using the geometric mean (calculations are given in the appendix). The questionnaire avoids the pressure on the experts and ensures the accuracy of the assessment, and the geometric mean allows us to generalize individual probability values (questionnaire results) using the formula:

$$
\pi_{i, j}=\sqrt[12]{\prod_{k=1}^{12} \pi_{i, j}} .
$$

As a result, we obtain a matrix of transient probabilities of Markov chain of Ltd. TMC «Lvivholod», which characterizes strategic planning of innovative activity:

$$
\left\|\pi_{i, j}\right\|=\left\|\begin{array}{cccccc}
0,20,3 & 0 & 0,4 & 0 & 0 & 0,1 \\
0 & 0,40,4 & 0 & 0 & 0 & 0,2 \\
0 & 0 & 0,60,4 & 0 & 0 & 0 \\
0 & 0 & 0 & 0,30,3 & 0 & 0,4 \\
0 & 0 & 0 & 0 & 0,60,4 & 0 \\
0 & 0 & 0 & 0 & 0,50,40,1 \\
0 & 0 & 0 & 0 & 0 & 0
\end{array}\right\| .
$$

To determine the error of modeling of strategic planning of innovative activity of Ltd. TMC «Lvivholod», let us do the simulation, using Kolesnikova K. V. sequence and the MS Excell analysis package. Using the RAND() function (in Russian interface), we obtain a uniformly distributed random number $\left(\xi_{i . j}=2 * \operatorname{RAND}()-1\right)$ in the range $[-1 ; 1]$. We use it to determine a random probability, using the formula [8]:

$$
\pi_{i, j}=\pi_{i, j}^{0} *\left(3+\xi_{i . j} * d / 100\right)
$$

where $\pi_{i, j}{ }^{0}$ - transitional probabilities of the strategic planning states of the enterprise, determined by the expert way;

$\mathrm{d}$ - relative calculation error accepted for $10 \%$ $(\mathrm{d} / 100=0,01)$.

Using the modeling recommendations given in [8], let us execute 10 runs of the simulation model (6) to determine the probability of transition states between the stages of strategic planning of innovative modeling of Ltd. TMC «Lvivholod». The results are summarized in Table.1. Numbers of run of the simulation model (table 1) determined by experts, who were included in the expert group of employees of the enterprise and scientists, economists, government officials etc. Probabilities of transition calculated by formula 6 . Additional criteria for the quality of the model are variance and the relative errors.

The variance is determined by the formula:

$$
\sigma^{2}=\frac{\sum_{i=1}^{n}\left(\pi_{i . j}-\overline{\pi_{l, j}}\right)^{2}}{n} \text {. }
$$


For the relative error is accepted the standard deviation of calculations $(\sigma)$.

Table 1. Simulation modeling of transition state probabilities between stages of strategic planning of innovative modeling of Ltd. TMC «Lvivholod»

\begin{tabular}{|c|c|c|c|c|c|c|c|c|c|c|c|c|c|c|c|c|c|c|}
\hline \multirow{2}{*}{$\begin{array}{c}\text { Run } \\
\text { number }\end{array}$} & \multicolumn{18}{|c|}{ Probabilities of transition } \\
\hline & $\vec{F}$ & $\stackrel{N}{F}$ & $\stackrel{F}{F}$ & $\hat{F}$ & $\overrightarrow{\mathrm{v}}$ & $\stackrel{N}{\tilde{N}}$ & $\hat{N}$ & $\stackrel{m}{m}$ & $\stackrel{+}{\tilde{m}}$ & $\stackrel{m}{*}$ & $\stackrel{+}{\stackrel{+}{*}}$ & $\hat{F}$ & 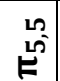 & $\begin{array}{l}\stackrel{0}{L} \\
\hat{k}\end{array}$ & 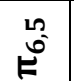 & 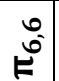 & $\hat{\hat{F}}$ & $\hat{N}$ \\
\hline 1 & $\begin{array}{l}8 \\
8 \\
0 \\
0 \\
0\end{array}$ & $0_{0}^{\infty}$ & $\stackrel{2}{=}$ & $\begin{array}{l}8 \\
8 \\
0 \\
0\end{array}$ & స్రి & స్ స్ & $\begin{array}{l}\overline{8} \\
0 \\
0\end{array}$ & $\stackrel{n}{2}$ & $\stackrel{2}{=}$ & $\approx$ & ๙ุ & స్ స్ & $\hat{\sigma}$ & શั & 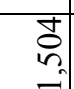 & స్రి & $\begin{array}{l}\overrightarrow{0} \\
\text { n. } \\
0\end{array}$ & $\begin{array}{lll}\infty \\
2\end{array}$ \\
\hline 2 & $\begin{array}{l}\text { तै } \\
\text { bे } \\
0 \\
0\end{array}$ & $\begin{array}{l}\hat{0} \\
\hat{\sigma} \\
0\end{array}$ & $\begin{array}{l}+ \\
- \\
-\end{array}$ & $\begin{array}{l}\overrightarrow{1} \\
\overrightarrow{0} \\
\text { ?े. } \\
0\end{array}$ & $\begin{array}{l}\hat{\sigma} \\
=\end{array}$ & $\begin{array}{l}\widehat{\widehat{\sigma}} \\
\hat{\sigma}\end{array}$ & $\begin{array}{l}0 \\
0 \\
\vdots \\
0 \\
0\end{array}$ & $\begin{array}{l}2 \\
2 \\
\infty \\
-1\end{array}$ & 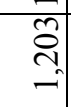 & $\begin{array}{l}\text { aे } \\
\text { ○े }\end{array}$ & बू. & 空 & ले & $\begin{array}{l}n \\
\tilde{o} \\
\infty \\
-1\end{array}$ & 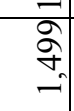 & $\begin{array}{l}\vec{a} \\
\stackrel{2}{=} \\
=\end{array}$ & $\begin{array}{l}0 \\
8 \\
0 \\
0 \\
0\end{array}$ & छे \\
\hline 3 & ڤે & $\begin{array}{l}2 \\
2 \\
0 \\
0\end{array}$ & $\begin{array}{l}\infty \\
\stackrel{\infty}{=} \\
=\end{array}$ & $\begin{array}{l}8 \\
8 \\
m \\
0\end{array}$ & 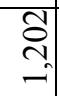 & స్ & $\begin{array}{l}\overrightarrow{0} \\
\dot{8} \\
0\end{array}$ & शे & $\begin{array}{l}2 \\
\Rightarrow\end{array}$ & 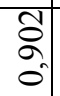 & 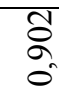 & న్రి & $\begin{array}{l}\circ \\
=\end{array}$ & श & $\underset{-}{\stackrel{g}{a}}$ & $\begin{array}{l}2 \\
= \\
=\end{array}$ & $\begin{array}{l}8 \\
8 \\
0 \\
0\end{array}$ & $\tilde{\varepsilon}$ \\
\hline 4 & $\begin{array}{l}\overline{0} \\
\vec{b} \\
0\end{array}$ & $\begin{array}{l}\bar{\Xi} \\
\hat{0}\end{array}$ & 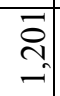 & $\begin{array}{l}8 \\
8 \\
m \\
0\end{array}$ & $\begin{array}{l}8 \\
8 \\
7 \\
-1\end{array}$ & 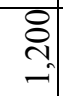 & $\begin{array}{l}8 \\
8 \\
0 \\
0\end{array}$ & श & $\begin{array}{l}\overrightarrow{\tilde{n}} \\
-\end{array}$ & 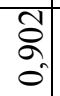 & $\begin{array}{l}\text { ते } \\
\text { مे }\end{array}$ & $\begin{array}{l}\text { ते } \\
\text { స్ }\end{array}$ & $\begin{array}{l}\hat{\sigma} \\
=\end{array}$ & $\begin{array}{l}2 \\
2\end{array}$ & $\begin{array}{l}n \\
0 \\
n \\
-1\end{array}$ & స్ & $\begin{array}{l}\overline{0} \\
\text { n. } \\
0\end{array}$ & $\stackrel{\Xi}{\varrho}$ \\
\hline 5 & के & $\begin{array}{l}\infty \\
\infty \\
0 \\
0\end{array}$ & $\begin{array}{l}\hat{\sigma} \\
\hat{=}\end{array}$ & $\begin{array}{l}\text { ลे. } \\
\text { ลे }\end{array}$ & $\begin{array}{l}\text { הి } \\
\text { त్ } \\
-1\end{array}$ & 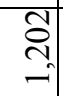 & $\begin{array}{l}\overrightarrow{3} \\
\overrightarrow{0} \\
0\end{array}$ & $\begin{array}{l}0 \\
0 \\
0 \\
-1\end{array}$ & 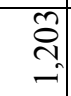 & $\begin{array}{l}\infty \\
\infty \\
0 \\
0\end{array}$ & $\begin{array}{l}\infty \\
\infty \\
\infty \\
0\end{array}$ & $\begin{array}{l}\hat{\sigma} \\
\hat{\sigma}\end{array}$ & $\begin{array}{l}2 \\
=\end{array}$ & হ & & $\begin{array}{l}\infty \\
\stackrel{\infty}{=} \\
=\end{array}$ & वे. & है \\
\hline 6 & $\begin{array}{l}8 \\
0 \\
0 \\
0\end{array}$ & $\begin{array}{l}\bar{\sigma} \\
\hat{\sigma}\end{array}$ & : & 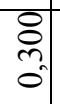 & 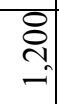 & 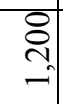 & $\begin{array}{l}8 \\
8 \\
0 \\
0\end{array}$ & $\begin{array}{l}\overrightarrow{0} \\
\infty \\
- \\
-\end{array}$ & $\begin{array}{l}2 \\
\Rightarrow\end{array}$ & $\begin{array}{l}1 \\
\hat{\alpha} \\
0 \\
0\end{array}$ & $\begin{array}{l}\widehat{T} \\
\hat{0} \\
0\end{array}$ & $\begin{array}{l}\hat{\sigma} \\
\hat{\theta}\end{array}$ & ஸે̊n & $\begin{array}{l}n \\
0 \\
\infty \\
-1 \\
-1\end{array}$ & $\begin{array}{c}m \\
\hat{n} \\
-1\end{array}$ & 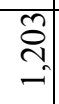 & $\begin{array}{l}\overline{0} \\
\text { ?. } \\
\text { o. }\end{array}$ & ఫొ \\
\hline 7 & $\begin{array}{l}\overline{8} \\
0 \\
0\end{array}$ & $\begin{array}{l}\text { वे. } \\
\text { o. }\end{array}$ & స్ & $\begin{array}{l}\overrightarrow{0} \\
m \\
0\end{array}$ & $\stackrel{2}{=}$ & $\stackrel{2}{\approx}$ & $\begin{array}{l}8 \\
8 \\
0 \\
0\end{array}$ & $\begin{array}{l}\infty \\
\stackrel{2}{=}\end{array}$ & 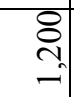 & $\begin{array}{l}\hat{\alpha} \\
\infty \\
0\end{array}$ & $\hat{\partial}$ & $\begin{array}{l}0 \\
\Rightarrow\end{array}$ & $\overrightarrow{\tilde{c}}$ & $\vec{\infty}$ & $\begin{array}{l}+ \\
\stackrel{0}{n} \\
-1\end{array}$ & స్త్రి & $\begin{array}{l}\overrightarrow{0} \\
\text { n. } \\
0\end{array}$ & छ̊ \\
\hline 8 & $\begin{array}{l}\overline{8} \\
0 \\
0\end{array}$ & 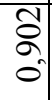 & $\begin{array}{l}1 \\
\text { స్ } \\
-1\end{array}$ & $\begin{array}{l}\bar{\sigma} \\
0 \\
0 \\
0\end{array}$ & $\begin{array}{c}1 \\
\\
-\end{array}$ & $\begin{array}{l}\widetilde{c} \\
\text { ָे }\end{array}$ & $\begin{array}{l}\overline{8} \\
\dot{0} \\
0\end{array}$ & $\begin{array}{l}0 \\
\tilde{\infty} \\
0 \\
-0\end{array}$ & $\begin{array}{l}\stackrel{\infty}{\circ} \\
=\end{array}$ & $\begin{array}{l}8 \\
\vdots \\
8\end{array}$ & 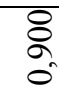 & \begin{tabular}{l}
8 \\
\multirow{n}{*}{} \\
-1
\end{tabular} & $\begin{array}{l}\hat{\sigma} \\
=\end{array}$ & $\stackrel{n}{\approx}$ & 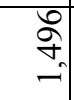 & $\begin{array}{l}\circ \\
\therefore \\
=\end{array}$ & $\begin{array}{l}\text { ते } \\
\text { ô. }\end{array}$ & ঃ \\
\hline 9 & $\begin{array}{l}\bar{B} \\
\overrightarrow{0} \\
0\end{array}$ & $\begin{array}{l}\vec{\vdots} \\
\text { ᄋ. }\end{array}$ & $\begin{array}{l}\overrightarrow{\mathrm{s}} \\
- \\
-\end{array}$ & $\begin{array}{l}8 \\
3 \\
m \\
0\end{array}$ & 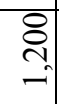 & $\begin{array}{l}\stackrel{8}{8} \\
\text { ה }\end{array}$ & $\begin{array}{l}8 \\
8 \\
0 \\
0\end{array}$ & \begin{tabular}{l}
2 \\
\multirow{2}{2}{}
\end{tabular} & 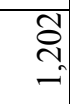 & $\begin{array}{l}1 \\
\hat{\alpha} \\
0 \\
0\end{array}$ & $\begin{array}{l}\widehat{\hat{D}} \\
0 \\
0\end{array}$ & $\begin{array}{l}0 \\
2 \\
=\end{array}$ & $\begin{array}{l}\hat{\vdots} \\
\end{array}$ & $\begin{array}{l}n \\
0 \\
\infty \\
0 \\
-1\end{array}$ & $\begin{array}{l}0 \\
\hat{n} \\
-1\end{array}$ & $\begin{array}{l}\text { ते } \\
\text { - }\end{array}$ & $\begin{array}{l}\overline{0} \\
\text { ?. } \\
0\end{array}$ & $\stackrel{\infty}{\infty}$ \\
\hline 10 & $\begin{array}{l}\text { हे } \\
\text { है }\end{array}$ & $\begin{array}{l}\infty \\
\infty \\
0 \\
0\end{array}$ & $\begin{array}{l}\infty \\
\stackrel{0}{=} \\
=\end{array}$ & $\begin{array}{l}\text { ते } \\
\text { oै }\end{array}$ & $\begin{array}{l}\infty \\
\stackrel{0}{=} \\
=\end{array}$ & $\begin{array}{l}\stackrel{\infty}{\varrho} \\
=\end{array}$ & $\begin{array}{l}\text { के } \\
\text { วิ }\end{array}$ & $\begin{array}{l}\infty \\
\stackrel{2}{=}\end{array}$ & \begin{tabular}{l} 
t) \\
\multirow{-}{*}{}
\end{tabular} & $\begin{array}{l}8 \\
\vdots \\
\vdots \\
0\end{array}$ & $\begin{array}{l}\text { ¿ू. } \\
\text { 。. }\end{array}$ & \begin{tabular}{l}
8 \\
\multirow{n}{*}{} \\
-1
\end{tabular} & 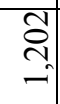 & $\begin{array}{l}\text { SI } \\
\infty \\
-0 \\
-1\end{array}$ & 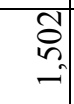 & $\begin{array}{l}\text { స్ } \\
-1\end{array}$ & $\begin{array}{l}8 \\
8 \\
3 \\
0\end{array}$ & $\ddot{c}$ \\
\hline$\overline{\pi_{l, j}}$ & $\begin{array}{l}8 \\
0 \\
0 \\
0\end{array}$ & $\begin{array}{l}8 \\
\grave{2} \\
0\end{array}$ & 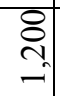 & $\begin{array}{c}8 \\
0 \\
m \\
0\end{array}$ & 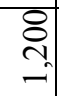 & $\begin{array}{l}\stackrel{\mathrm{N}}{-} \\
-1\end{array}$ & $\begin{array}{l}8 \\
8 \\
0 \\
0\end{array}$ & $\begin{array}{l}8 \\
\infty \\
-1\end{array}$ & 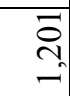 & 8 & $\begin{array}{l}\AA \\
\vdots \\
0\end{array}$ & $\begin{array}{l}2 \\
\Rightarrow\end{array}$ & 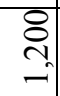 & 8 & $\begin{array}{l}\vec{B} \\
n \\
-0\end{array}$ & 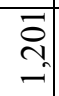 & $\begin{array}{l}8 \\
\text { m. } \\
0\end{array}$ & $£$ \\
\hline$\overline{\sigma^{2}}$ & $\begin{array}{l}1 \\
8 \\
8 \\
8 \\
8 \\
0\end{array}$ & $\begin{array}{l}8 \\
0 \\
0\end{array}$ & $\begin{array}{l}8 \\
8 \\
\vdots \\
0\end{array}$ & $\begin{array}{l}8 \\
0 \\
0\end{array}$ & $\begin{array}{l}\bar{a} \\
+ \\
0\end{array}$ & $\begin{array}{l}\vec{s} \\
\stackrel{+}{+}\end{array}$ & $\begin{array}{l}8 \\
8 \\
0 \\
0\end{array}$ & 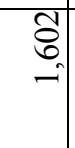 & $\begin{array}{l}\overline{0} \\
+ \\
0\end{array}$ & $\begin{array}{l}8 \\
0 \\
0\end{array}$ & $\begin{array}{l}8 \\
\frac{8}{0}\end{array}$ & $\begin{array}{l}8 \\
\vdots \\
\vdots \\
0\end{array}$ & $\begin{array}{l}3 \\
\text { है } \\
0\end{array}$ & $\hat{\tilde{n}}$ & 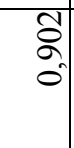 & $\begin{array}{l} \\
\\
0 \\
0\end{array}$ & $\begin{array}{l}8 \\
0 \\
0\end{array}$ & \& \\
\hline $\begin{array}{r}\text { Relativ } \\
\text { errors }\end{array}$ & $\begin{array}{l}\vec{Z} \\
0 \\
0\end{array}$ & $\begin{array}{c}\overrightarrow{6} \\
\vec{m}\end{array}$ & 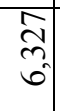 & $\begin{array}{c}\vec{r} \\
\frac{m}{m}\end{array}$ & $\begin{array}{l}\hat{n} \\
\hat{\sigma} \\
0\end{array}$ & लె & $\begin{array}{l}\overrightarrow{0} \\
0 \\
0\end{array}$ & $\begin{array}{l}\infty \\
0 \\
\vdots \\
ר\end{array}$ & $\begin{array}{l}\text { m్ } \\
\text { ?ె. }\end{array}$ & $\begin{array}{c}\text { b } \\
\stackrel{n}{m}\end{array}$ & $\frac{\pi}{m}$ & 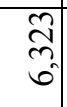 & $\begin{array}{l}\vec{\nabla} \\
\text { कु. }\end{array}$ & $\begin{array}{l}\infty \\
0 \\
0 \\
\mathfrak{d}\end{array}$ & $\begin{array}{l}u \alpha \\
\hat{\alpha} \\
\sigma\end{array}$ & $\overrightarrow{\widetilde{n}}$ & $\begin{array}{l}\overrightarrow{3} \\
m\end{array}$ & $\infty$ \\
\hline
\end{tabular}

According to the obtained results, the relative error of modeling does not exceed $13 \%$ except the simulation modeling of the state of strategic planning $\mathrm{S}_{5}$ (Fig. 3).

\section{Conclusion}

In order to improve the efficiency of enterprise's management, we have used the Markov chain to model strategic planning of innovative activity of the enterprise in the article. For this purpose, strategic planning of innovative activity of the enterprise is presented as a set of interacting state identifiers (Fig. 1), on the basis of which was formed the Markov chain graph (Fig. 2). This allowed us to generate a Markov Transition Probability Matrix (4), which can be used to estimate the probability of a strategic planning process being in each state over a period of time. In further studies on the problem it should be carried out simulation modeling of strategic planning of innovative activity of the enterprise, which determines the variability of the probability of its states, which indicates the level of its implementation in enterprises.

The advantages of the proposed model are the simplicity of calculations associated with the modeling of strategic planning processes in the enterprise. The obtained results are characterized by accessibility for their users from among the managers of the enterprise. We have also noted the absence of special requirements for information, technical and resource support of modeling processes at the enterprise. 


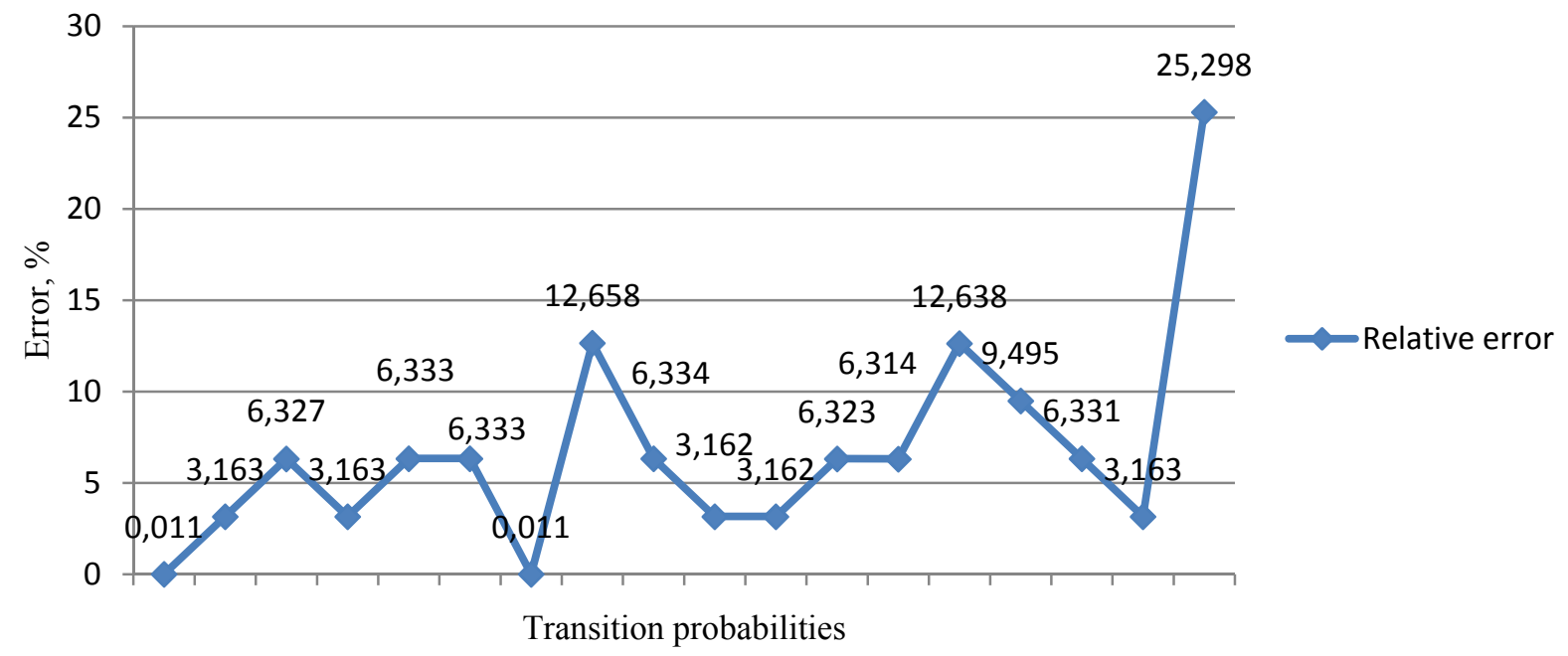

Fig. 3. Relative errors of the simulation modeling of the probability of transition states between the stages of strategic planning of innovative modeling of Ltd. TMC «Lvivholod».

At the same time, the model is not without its disadvantages, which are a subjective result of expert assessments, moreover, it needs for additional verification of the results of their analysis, determining the consistency of judgments, and so on. Obtaining more reliable results is associated with an increasing complexity of modeling processes and an increasing the number of runs of the simulation model. Other limitations of the model are the obligation to use all states of strategic planning processes of enterprise innovation activity (Fig. 1).

Proposed model can be extended by combining with the processes of modeling tactical planning of innovative activities of the enterprise, as well as modeling of tactical approaches of the enterprise based on the results of strategic planning.

\section{References:}

[1] Zakharchenko V. I., Korsikova N. M. and Merkulov M. M. Innovation management: theory and practice in the conditions of economic transformation. Textbook - K.: Center for Educational Literature, 2012. 448 p.

[2] Kuzmin O.Ye. and Melnyk O. G. Fundamentals of Management: textbook. 2-nd ed. K.: Akademvidav, 2007. $464 \mathrm{p}$.

[3] Prystavka P. O. and Tyvodar O. V. Model based on Markov chains in the problem of making decisions about buying or selling material assets. Actual problems of automation and information technology, 2017, Vol.21: 132-142.
[4] Markov A.A. Propagation of the law of large numbers into quantities that depend on each other. News of the Physical and Mathematical Society at Kazan University, 1906, 2-nd series, Vol. 15: 135-156.

[5] Meyn S. P. and Tweedie R. L. Markov Chains and Stochastic Stability. London: SpringerVerlag, 1993. ISBN 0-387-19832-6

[6] Shpak N., Odrekhivskyi M., Doroshkevych K. and Sroka W. Simulation of Innovative Systems under Industry 4.0 Conditions. Social Sciences. MDPI AG.8, 2019, 7. Available online: https://www.mdpi.com/2076-0760/8/7/202. doi:10.3390/socsci8070202

[7] Skitsko V.I. Use of Markov chains for the estimation of indicators of the credit policy of the enterprise. Economics and forecasting, 2009, 3: 144-155.

[8] Kolesnikova K. V. Development of project management theory: justification Koshkina's K. $\mathrm{V}$. law on project completion. Management of complex systems development, 2013, 16: 38-45. Available online: http://nbuv.gov.ua/UJRN/Urss_2013_16_10.

[9] Olekh T. M. The use of Markov chains for the study of multidimensional estimates in project management. Ways of realization of creditmodule system of organization of educational process and test forms of control of students' knowledge: collection of materials of scientificmethodical seminar, 2015, 10: 64-68.

[10] Ikhsanov Sh. M. and Lopushanska V. V. Using Markov chains for predicting socio-economic 
processes. Actual problems of the economics, 2011, 1 (115): 259-267.

[11] Lapshyn V. I. and Kuznichenko V. M. The scarce model of investment project management in the regions. Business Inform, 2013, 6: 57-62. Available online: http://nbuv.gov.ua/UJRN/binf_2013_6_11.

[12] Aliiev F. M. Control of the movement of material flows based on the Markov chain. Scientific Bulletin of Uzhgorod National University. Series: International Economic Relations and the World Economy, 2019, 24(1): 14-18. Available online: http://nbuv.gov.ua/UJRN/Nvuumevcg_2019_24 (1) 5 .

[13] Babenko, V. Formalization of the Model of Management of the Technological Innovations. CEUR Workshop Proceedings, 2019, 2393: 595-602. Available online: http://ceurws.org/Vol-2393/. URL: http://ceur-ws.org/Vol2393/paper 431.pdf

[14] Ramazanov, S., Antoshkina, L., Babenko, V. and Akhmedov, R. Integrated model of stochastic dynamics for control of a socioecological-oriented innovation economy. Periodicals of Engineering and Natural Sciences, 2019, vol. 7 (2): 763-773. doi: http://dx.doi.org/10.21533/pen.v7i2.557

[15] Babenko, V., Lomovskykh, L., Oriekhova, A., Korchynska, L., Krutko, M., Koniaieva, Y. Features of methods and models in risk management of IT projects, Periodicals of Engineering and Natural Sciences, 2019, vol. 7 (2): 629-636. doi: http://dx.doi.org/10.21533/pen.v7i2.558

[16] Salakhutdinov R., Mnih A. Bayesian probabilistic matrix factorization using Markov chain Monte Carlo. ICML '08: Proceedings of the 25th international conference on Machine learning, July 2008: 880-887. doi: https://doi.org/10.1145/1390156.1390267

[17] Zheng Yuan Prediction of protein subcellular locations using Markov chain models. FEBS Letters. 1999. Vol., Issue 1: 23-26. doi: https://doi.org/10.1016/S0014-5793(99)005062

[18] Radford M. Neal Markov Chain Sampling
Methods for Dirichlet Process Mixture Models. Journal of Computational and Graphical Statistics. 2000 Vol. 9. Issue 2: 249-265.

doi:https://www.tandfonline.com/doi/abs/10.1080/10 618600.2000 .10474879

[19] Jiang, Yi, Saito, Mitsuru \& Sinha, Kumares C. Bridge performance prediction model using the Markov chain. Transportation Research Record 1988. Issue 1180: URL:http://onlinepubs.trb.org/Onlinepubs/trr/1 988/1180/1180-005.pdf

[20] Singer P, Helic D, Taraghi B, Strohmaier M (2014) Detecting Memory and Structure in Human Navigation Patterns Using Markov Chain Models of Varying Order. PLOS ONE 9(7): e102070. doi:10.1371/journal.pone.0102070

[21] Peskun P. H. Optimum Monte-Carlo sampling using Markov chains. Biometrika. 1973. Volume 60. Issue 3: 607-612. Doi: https://doi.org/10.1093/biomet/60.3.607

[22] Prowell S.J. Using Markov Chain Usage Models to Test Complex Systems. Proceedings of the 38th Annual Hawaii International Conference on System Sciences. 2005. Doi: 10.1109/HICSS.2005.663

[23] Sarukkai Ramesh R. Link prediction and path analysis using Markov chains. Computer Networks. 2000. Volume 33, Issues 1-6: 377$386 . \quad \mathrm{https} / / /$ doi.org/10.1016/S13891286(00)00044-X

[24] Shamshad A., Bawadi M.A., Hussin Wan W.M.A., Majid T.A., Sanusi S.A.M. First and second order Markov chain models for synthetic generation of wind speed time series. Energy. 2005. Volume 30, Issue 5: 693-708. Doi:https://doi.org/10.1016/j.energy.2004.05.02 6

[25] Yang Xin, Zheng Xin-Qi, Lv Li-Na A spatiotemporal model of land use change based on ant colony optimization, Markov chain and cellular automata. Ecological Modelling. 2012. Volume 233: 11-19. Doi:https://doi.org/10.1016/j.ecolmodel.2012.0 3.011 